Abraham in Arms 


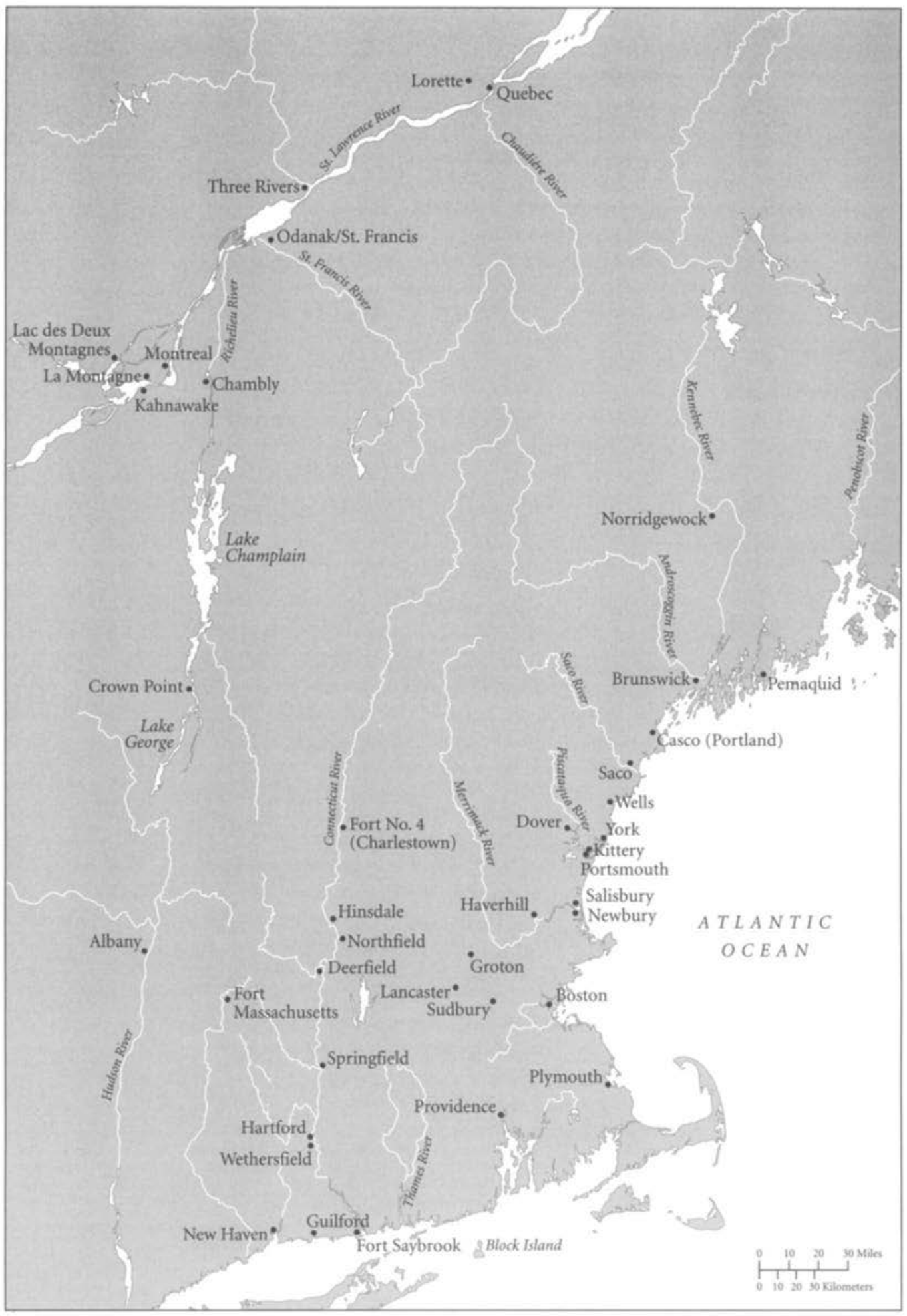




\title{
Abraham in Arms
}

War and Gender in Colonial New England

\author{
Ann M. Little
}

$\overline{\text { PENN }}$

University of Pennsylvania Press Philadelphia 


\section{EARLY AMERICAN STUDIES}

\section{Daniel K. Richter and Kathleen M. Brown, Series Editors}

Exploring neglected aspects of our colonial, revolutionary, and early national history and culture, Early American Studies reinterprets familiar themes and events in fresh ways. Interdisciplinary in character, and with a special emphasis on the period from about 1600 to 1850 , the series is published in partnership with the McNeil Center for Early American Studies.

A complete list of books in the series is available from the publisher.

Copyright $(\mathbb{C} 2007$ University of Pennsylvania Press

All rights reserved

Printed in the United States of America on acid-free paper

$\begin{array}{llllllllll}10 & 9 & 8 & 7 & 6 & 5 & 4 & 3 & 2 & 1\end{array}$

Published by

University of Pennsylvania Press

Philadelphia, Pennsylvania 19104-4112

Library of Congress Cataloging-in-Publication Data

Little, Ann M.

Abraham in arms : war and gender in Colonial New England / Ann M. Little.

p. cm. - (Early American studies)

Includes bibliographical references and index.

ISBN: 978-0-8122-1961-6

1. New England-History-Colonial period, ca. 1600-1775. 2. Frontier and pioneer life-New England. 3. New England-History, Military. 4. New England-Social conditions. 5. Masculinity-New England-History. 6. Sex role-New England-History. 7. English-New England-History-18th century. 8. Indians of North America-New England-History. 9. French-New England-History-18th century. 10. New England-Ethnic relations. I. Title. II. Series.

F7. $.68 \quad 2006$

$974^{\prime} .02-d c 22$ 2006042166

Frontispiece: Northeastern borderlands, ca. 1670-1763 
For C.P.M. 
